\title{
THE RIGHTS AGAINST THE OBLIGATIONS OF THE ACCOUNTANTS
}

\author{
Janka Dimitrova ${ }^{1}$, Blagica Koleva², Eftimija Dimitrova ${ }^{3}$
}

UDC $\quad 657: 340.13(497.7)$

657-057(497.7)

1 "Goce Delcev" University - Faculty of Economics - Stip, Republic of North Macedonia, janka.dimitrova@ugd.edu.mk

2 "Goce Delcev" University - Faculty of Economics - Stip, Republic of North Macedonia, blagica.koleva@ugd.edu.mk

${ }^{3}$ University of London - London, United Kingdom, eftimijadimitrova@yahoo.com

\section{Abstract}

Quality, timely and accurate information is extremely important for making a timely and accurate decisions. A large number of stakeholders (owners, management, employees, customers, suppliers, investors, financial institutions, the state, ....) are interested in the operation of business entities. The most reliable source of information on the financial operations of business entities are the audited financial statements prepared in accordance with International Financial Reporting Standards. The responsibility for preparing the financial statements lies $w$-ith the management but in practice the responsibility for the truthfulness and accuracy of the information presented in the financial statements lies with the certified accountant. Even during the Covid-19 pandemic, accountants worked tirelessly on all the risk posed by the pandemic and gave support to the business sector to apply for the anti-crisis measures.

The obligation and responsibility of the accountant for the accuracy and completeness of the information presented in the financial statements arises in a number of laws (the Law on Accounting, the Law on Trade Companies, the Law on Securities, ...), which prohibits the certified accountant to sign incorrect or incomplete financial statements, i.e. financial statements that cause delusion and which are contrary to international financial reporting standards.Accountants are the core of the economy, an important link between the state and the business sector, responsible for calculating and collecting taxes that fill the budget, business sector consultants.

How proud this sounds!

But do accountants really feel proud in practice? In 2012, the Law on Accounting was adopted, which was expected to put order in the profession and raise it to the pedestal it deserves. Therefore, the purpose of this paper is to conduct research to identify the rights and obligations of accountants and how much accountants believe that there is a balance between rights, responsibilities and obligations. The research will be conducted by means of a questionnaire submitted to the accounting companies registered in the register of ISOS (Institute of Accountants and Certified Accountants). According to the answers to 
the questionnaire, we will give suggestions for overcoming the problems and improving the situation in which this extremely important profession finds itself.

\section{Keywords: Law on Accounting, Accountants, Rights, Obligations, Responsibilities Introduction}

The profession of accountant in the Republic of Macedonia until 2002 was regulated by the Law on Accounting ("Official Gazette of the Republic of Macedonia no. 42/93, 48/93, 6/95, 32/98, 39/99 and 70/01), according to which each entity was obliged to entrust the management of accounting to a professional accountant (1).

In 2012, the Law on Accounting was finally adopted.

According to the definitions in the Law on Accounting:

- "Accountant" is a natural person who has a certificate of accountant from the Institute of Accountants and Certified Accountants of the Republic of Macedonia (ISOS) and which is registered in the Register of Accountants of ISOS.

- "Certified Accountant" is a natural person who has a certificate of certified accountant from ISOS and which is registered in the Register of Certified Accountants of ISOS.

- "Accountant" is a natural or legal person who is obliged to keep trade / business books and to compile and present annual accounts and / or financial reports in accordance with law (2)

The accountants and authorized accountants on the territory of the Republic of Macedonia are organized in the Institute of Accountants and Chartered Accountants of the Republic of Macedonia (ISOS).The Institute is a professional association of accountants and authorized accountants established in accordance with the Law on Accounting Practices and was established in order to promote the accounting profession and organized work of the accountants and authorized accountants in the territory of the Republic of Macedonia. The Institute is an independent, non-political and non-profit organization, in which accountants and certified accountants are members, regardless of their national, religious, racial or other background. (3)

A number of legal regulations that should be applied and respected by the accountants, prescribe penalties and criminal responsibilities for both the legal entity and the responsible person of the legal entity. The profession of accountant / certified accountant carries on its shoulders responsibilities and obligations to respect and properly apply all legal solutions in order to perform their job well and timely and accurate information presented in the financial statements on the one hand and not to face penalties and criminal liabilities for themselves, penalties for accounting companies and penalties and criminal liabilities for responsible persons of accounting companies.

The Chamber of Accountants of Macedonia strongly advocates for the realization of the rights of accountants who are left without a functional law and left to themselves. For years, the Chamber of Accountants has reacted to the repressive role of the Ministry of Finance and its role in destroying the accounting profession. (4)

For the rights and obligations of accountants / certified accountants during their operations, we conducted a survey through a questionnaire that contained 15 questions. The questionnaire was submitted to the accounting firms registered in the ISOS register. The questionnaire was 
distributed through the Google Forms application, which based on the answers to the questions, automatically created the graphs.

The questionnaire was answered by 291 accountants, so we believe that the answers are relevant to ascertain the situation and make suggestions for overcoming the problems faced by accountants to improve the situation.

\section{The rights and obligations of accountants through the prism of the Law on Accounting}

Pursuant to Article 15 of the Law on Accounting, the person who wants to acquire the status of accountant or certified accountant submits a written request to the Institute to obtain a certificate for accountant, i.e. certified accountant.

- The request for obtaining a certificate for accountant must be accompanied by: proof (certificate) for completed secondary economic education and a certificate from an employer for work experience of at least three years in the field of accounting, or proof (certificate) for completed three-year higher education in the field of economics or business, i.e. completed studies according to the Bologna Declaration and has 180 credits according to the European Credit Transfer System (ECTS) and a confirmation from an employer for work experience of at least two years in the field of accounting, or (proof) certificate of completed four years of higher education (VII / 1 degree) in the field of economics or business, i.e. completed studies according to the Bologna Declaration and has 240 credits according to the European Credit Transfer System (ECTS) and a confirmation from an employer for work experience of at least one year in the field of accounting.

- The application for obtaining a certificate for certified accountant must be accompanied by: certificate for completed four years of higher education (VII / 1 degree) in the field of economics or business, i.e. completed studies under the Bologna Declaration and has 240 credits according to the European Credit Transfer System (ECTS) and a confirmation from an employer for work experience of at least three years in the field of accounting.

In order to perform accounting activities for its own needs, the company for keeping accounting can hire an accountant and / or certified accountant or with a contract for performing accounting activities to hire a sole trader-accountant, sole proprietor, certified accountant or company.

- Sole trader - accountant performs accounting activities for sole proprietors and associations and foundations.

- Sole trader - certified accountant performs accounting activities for sole proprietors, associations and foundations and other non-profit organizations and limited liability companies.

- Company for performing accounting activities performs accounting activities for all companies for keeping accounting. The accounting firm must have at least one accountant and one chartered accountant.

The law prescribes professional liability insurance (for accounting), as follows: 
- for sole proprietor-accountant in the amount of at least 2,000 euros in denar counter value after a harmful event,

- for sole proprietor-certified accountant in the amount of minimum 5,000 euros in denar counter value after a harmful event and

- for a company for performing accounting activities in the amount of at least 20,000 euros in denar counter value after a harmful event.

Accountants and certified accountants have an obligation to constantly upgrade their knowledge and skills by attending Continuing Professional Development (CPD) classes. "Continuous professional development" is a continuous professional development in order to upgrade the theoretical and practical knowledge and skills for professional and efficient performance of accounting work. (5)

Pursuant to Article 19 of the Law on Accounting, in order to upgrade the knowledge in the field of accounting, accountants are obliged to attend training for continuous professional development of at least 90 hours for a period of three years, with at least 20 hours during one year. In order to upgrade the knowledge in the field of accounting, the certified accountants are obliged to attend training for continuous professional development of at least 120 hours for a period of three years, with at least 30 hours during one year.

The training for CPD is organized and implemented by the Institute in cooperation with other legal entities that conduct professional development and education in the field of accounting, finance or taxes and individuals with appropriate qualifications in the mentioned areas. After completing the trainings, the accountant, i.e., the certified accountant takes an exam to check the knowledge. The accountant, i.e., the certified accountant who will not pass the exam for checking the knowledge is deleted from the register in which he / she is registered.

The law does not prescribe the manner of working conditions that should be provided to accountants / certified accountants, as well as the basis for determining the remuneration / salary for the performed accounting activities.

\section{Experiences with the Association of Chartered Certified Accountants (ACCA)}

ACCA is the world's most forward-thinking professional accountancy body. ACCA believe that accountancy is vital for economies to grow and prosper, which is why it work all over the world to build the profession and make society fairer and more transparent. ACCA have more than 233,000 fully qualified members and 536,000 future members worldwide. They're among the world's best-qualified and most highly sought-after accountants - and they work in every sector you can imagine.

Organisations know and trust ACCA's designation. They are out there every day, connecting with businesses large and small, governments, educational establishments and opinion formers. They are on top of emerging trends, legislation and legal requirements, helping to shape them. Because of all this, ACCA is able to create the innovative, strategic-thinking accountants our fast-changing world needs. (6)

ACCA, as an international association of certified accountants, prescribes a procedure for obtaining an (internationally recognized) license for certified accountant, where a person who has 
completed at least secondary education (regardless of the field) can apply. The program and literature for taking exams are prescribed. To become a member of ACCA, in addition to passing the exams, the candidate must have 3 years of work experience in accounting under the supervision of a certified accountant.

The person who became a member of ACCA must upgrade their knowledge by visiting the CPD, attending literature in the field of accounting, acquiring other knowledge and skills, attending conferences and congresses, etc., and for these requires a certificate only for $50 \%+1$ hour of the prescribed CPD hours for certified accountants.

\section{Research results}

In this section, the research questions, the answers as well as commentary will be given.

1. Does the current Law on Accounting adequately balance the obligations and rights of accountants / certified accountants and accounting firms?

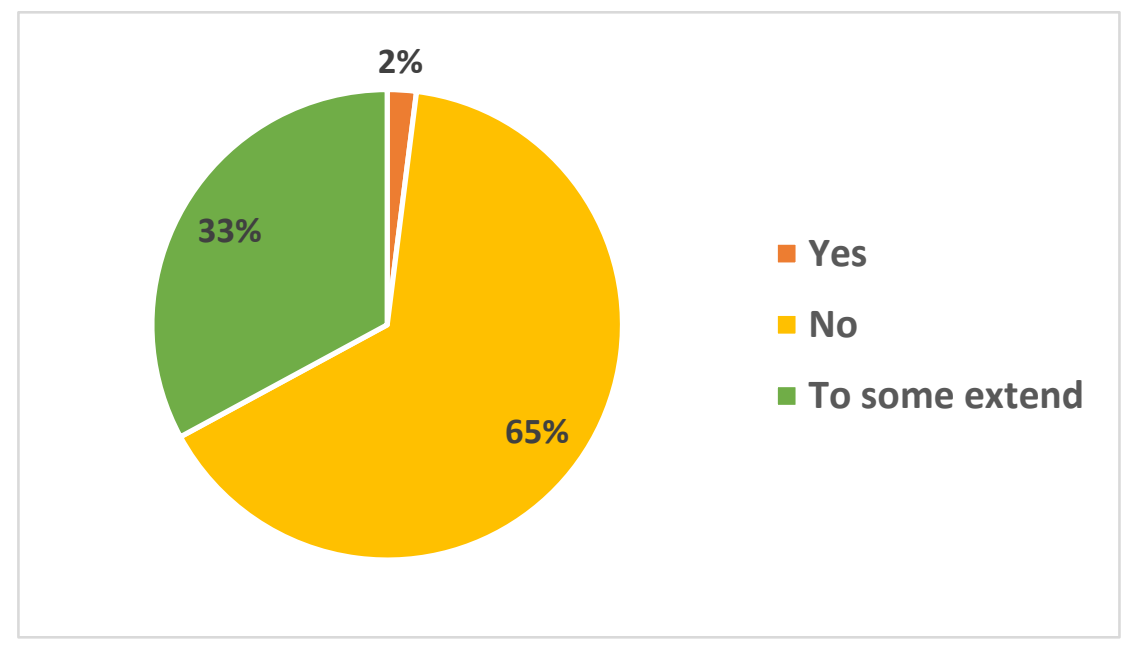

As many as $65 \%$ of accountants think that the current Law on Accounting does not balance the obligations and rights of accountants / certified accountants and accounting firms. Only $2 \%$ think that rights and obligations are properly balanced. 
2. If you answered the previous question with no or to some extent, in your opinion the accountants have:

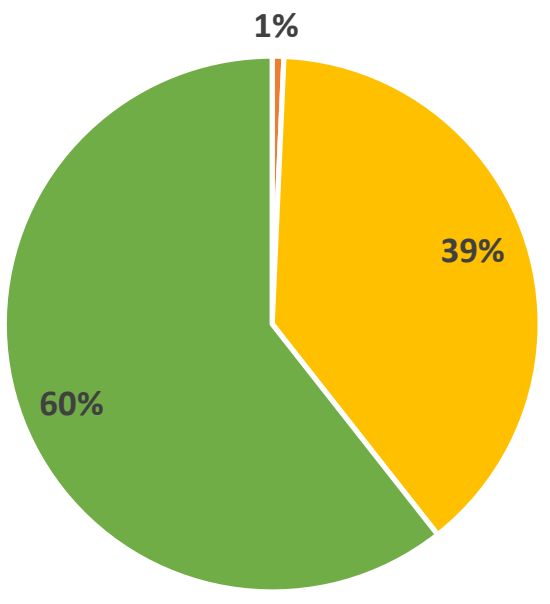

- More rights than obligations

- More obligations than rights

- No rights, just obligations

It is worrying that as many as $60 \%$ of accountants think that the current law on accounting works imposes only obligations on accountants.

3. Which of the following criteria (by education) do you consider appropriate for obtaining an accountant / chartered accountant license?

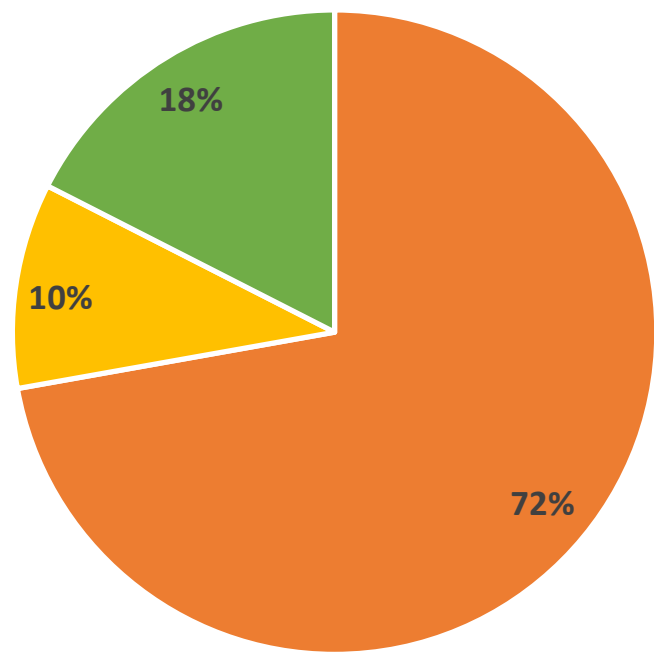

- Secondary (for accountant) or higher education (for certified accountant) in the field of economic sciences, with work experience of at least 3 years under the supervision of a certified accountant

- Secondary (for accountant) or higher education (for certified accountant) in any field, with work experience of at least 3 years under the supervision of a certified accountant

- Any person with a minimum secondary education who has passed the exams for obtaining a license for accountant / certified accountant and has work experience of at least 3 years under the supervision of a certified accountant

The opinion of $72 \%$ of the accountants is that in order to obtain a license for accountant / certified accountant they should have completed secondary / higher education (respectively). 
4. An accounting firm should have employed:

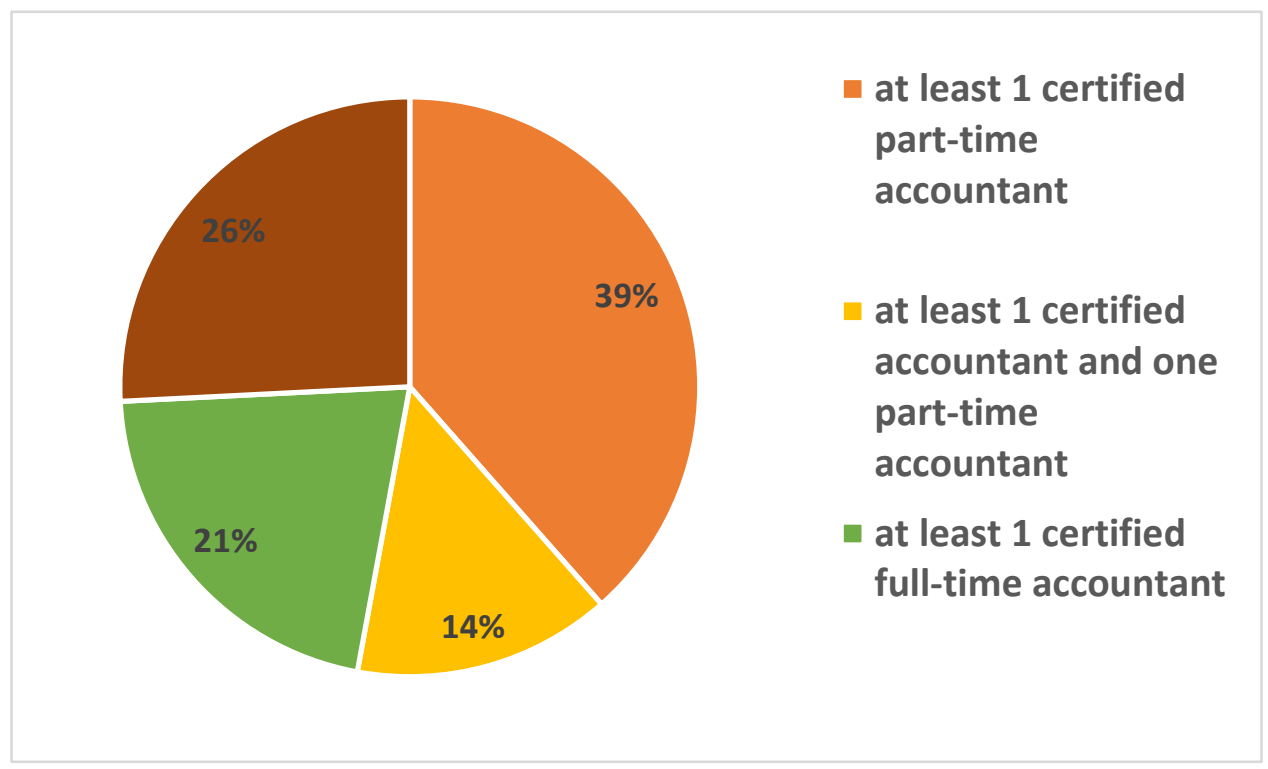

The company for performing accounting activities should have employed at least one certified accountant and thus they will be equal to the conditions for establishing a sole proprietor accountant / certified accountant.

5. Annual accounts, financial reports and forms submitted to the Public Revenue Office should be signed by (you can choose more answers):

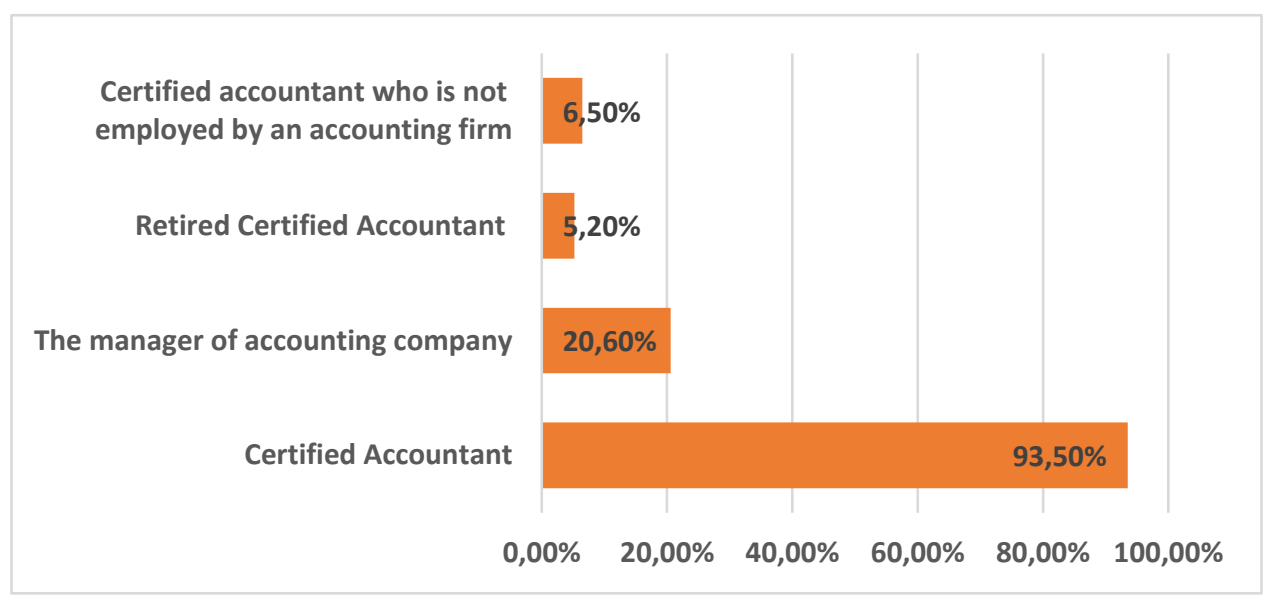

$93.5 \%$ of the accountants think that the annual accounts and financial reports should be signed by certified accountants. In that way, the unfair competition from pensioners and persons who are not employed in the accounting firms and in the companies for performing accounting activities will be prevented. 
6. Accountants and certified accountants should constantly upgrade their knowledge through: (you can choose multiple answers):

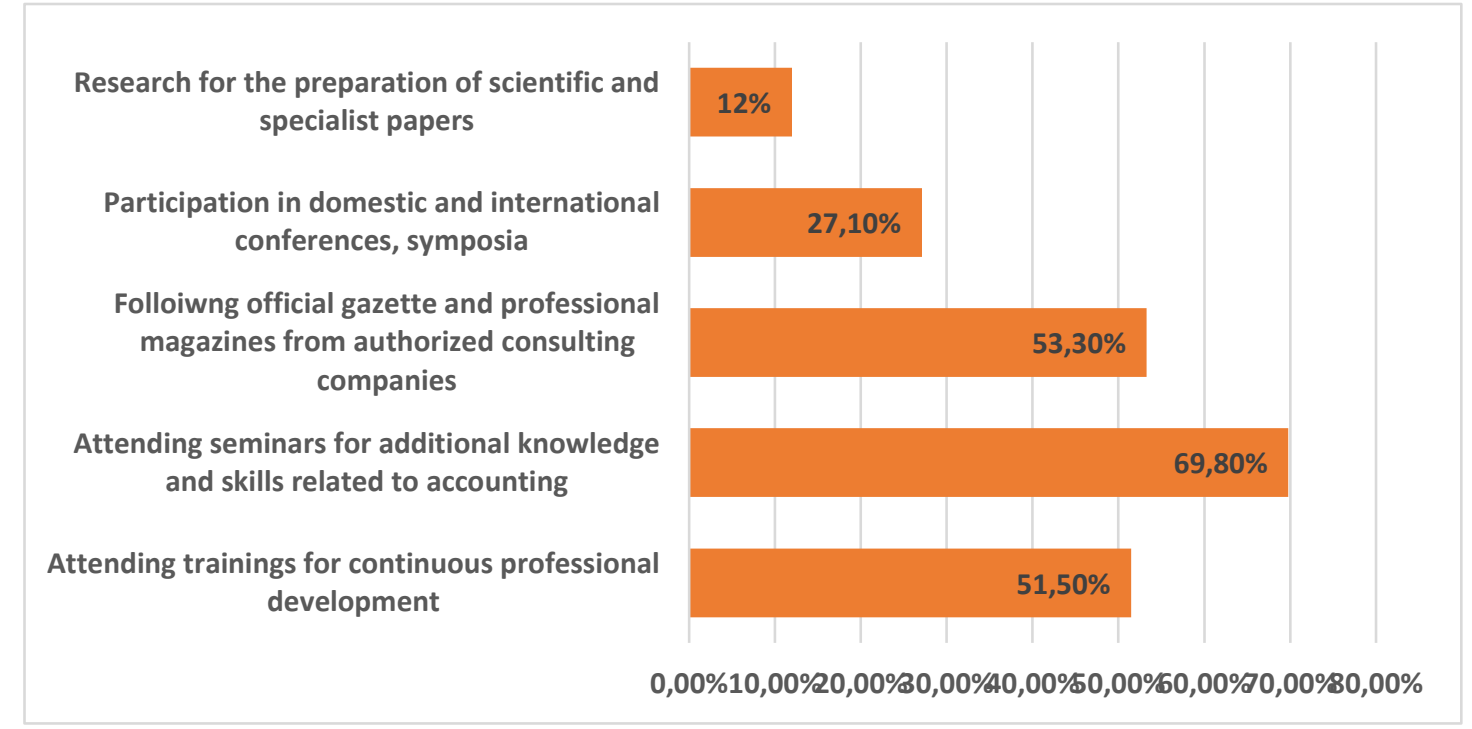

Most of the accountants think that they should constantly upgrade their knowledge and skills by attending seminars related to accounting, continuing professional development (CPD) and following the official gazette and other additional literature.

7. From the prescribed hours per year for CPD, should:

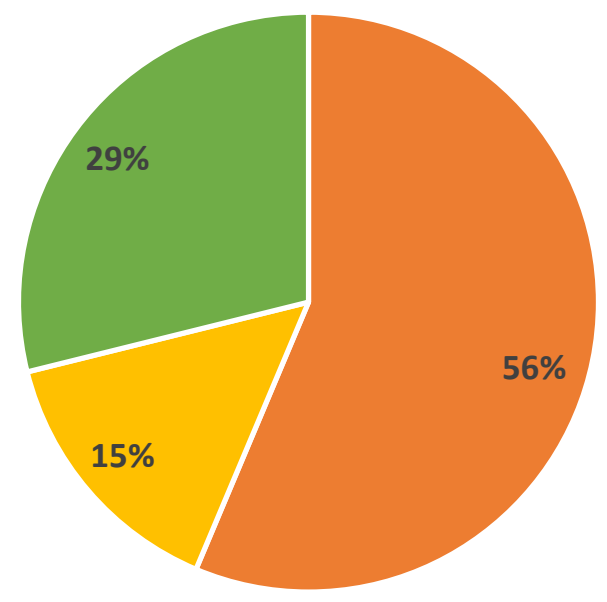

- To have a certificate for all classes

- For at least $50 \%+1$ hour to have a certificate / confirmation and upon request to be presented to an appropriate body / commission

- You do not need to have a certificate at all

Additionally, $56 \%$ of the accountants are of the opinion that all the prescribed classes for CPD should have proof (certificate). ACCA requires a certificate for only $50 \%+1$ hour of the attended hours for the CPD of certified accountants. 
8. The trainings for continuous professional development should be organized by:

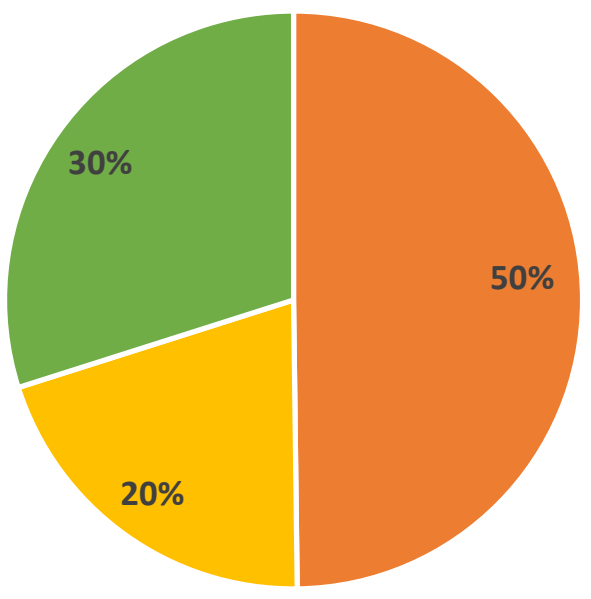

- Institute of Accountants and Chartered Accountants

Chamber of Accountants

- Authorized consulting companies

Almost $50 \%$ of the accountants think that CPD should be organized by ISOS, as a professional association of accountants and certified accountants in order to promote the accounting profession and organized action of accountants and certified accountants on the territory of the Republic of Macedonia.

9. Continuing professional development training should be given by Practitioners with:
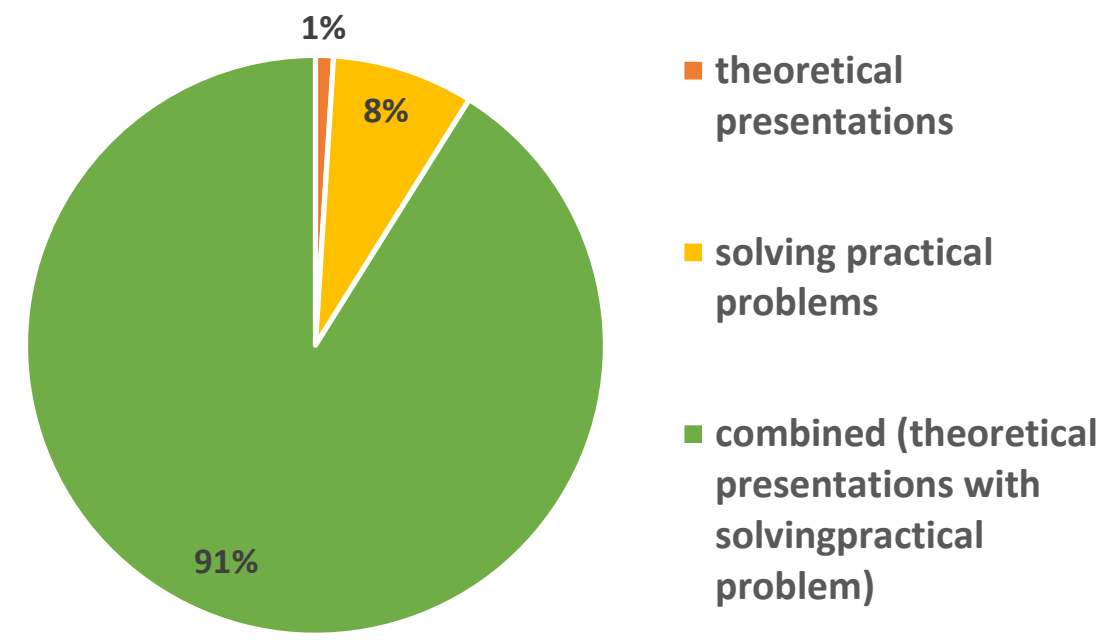

Performers of trainings for CPD should be experts from practice and they should be combined (theoretical presentations with solving practical problems), is the opinion of $91 \%$ of accountants. 
10. Continuous professional development trainings should be held:

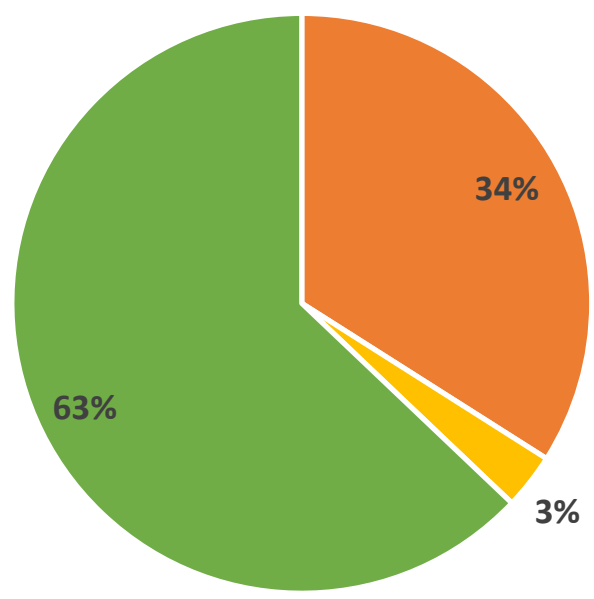

- By physical presence

- Online through electronic platforms

- Combined (depending on the participant's choice)

The trainings are most practically performed in combination (with physical presence or online through electronic platforms), depending on the choice of the participant is the opinion of $63 \%$ of the accountants. This is due to the fact that in that way the additional travel, daily and accommodation costs for physical attendance at the trainings would be reduced.

11. The price for the trainings should be:

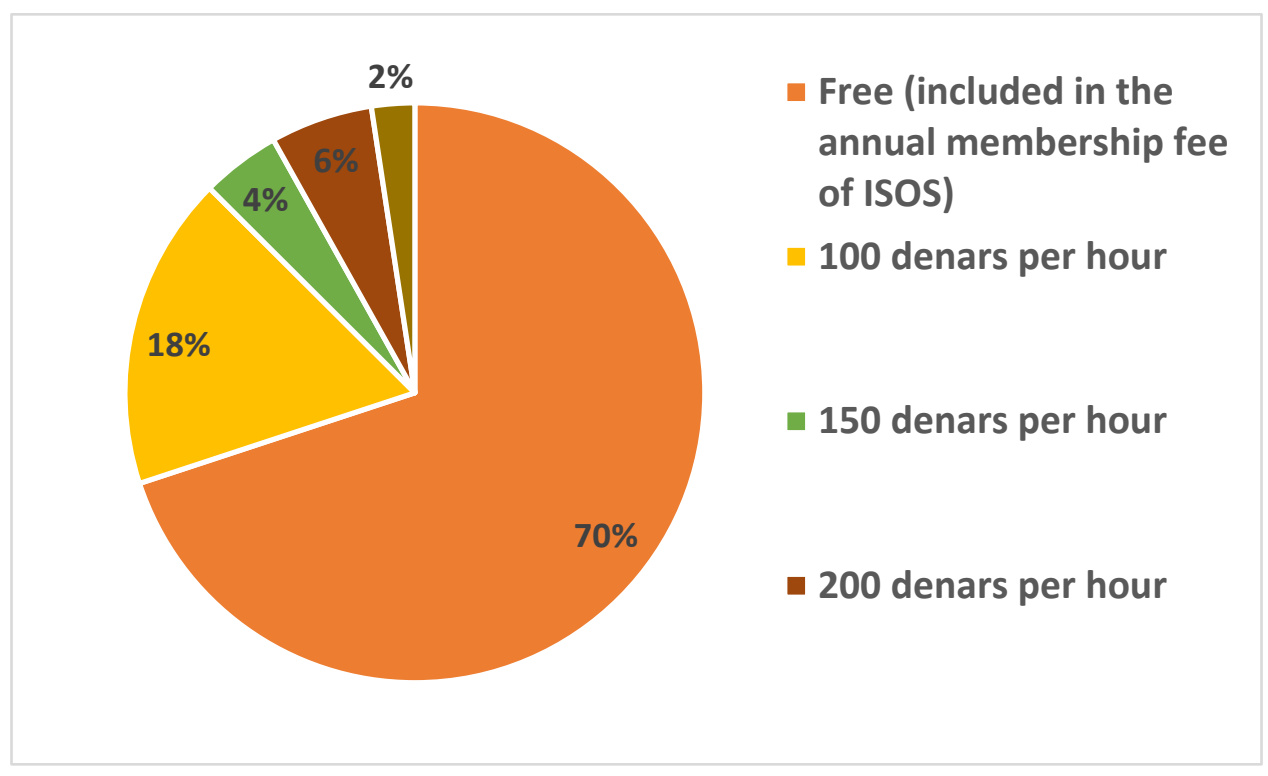

$70 \%$ of the accountants are of the opinion that the trainings should be free, i.e. included in the membership fee that the accountants pay to ISOS. 
12. Once acquired, the license for certified accountant should be automatically renewed on the basis of:

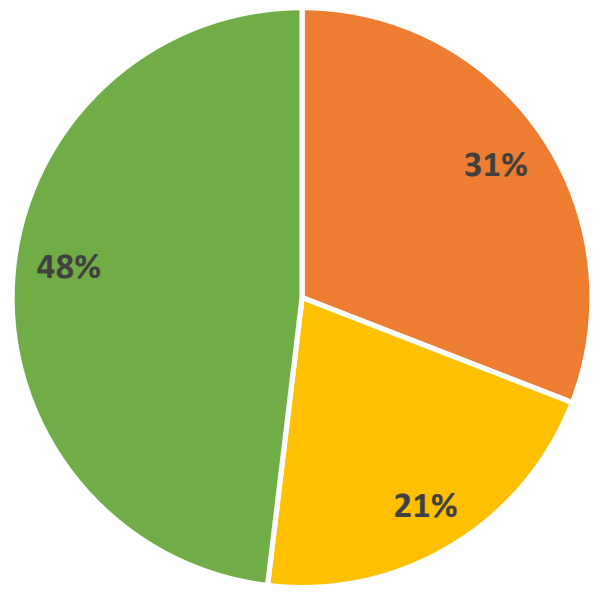

- Attended classes for continuous professional development

- Signed and submitted at least one annual account

- No extension of licenses is required

Once acquired, the license for an accountant should be permanent and unconditional, according to $48 \%$ of accountants. These answers are illogical and contrary to the answers to question number 6 where most of the accountants are of the opinion that they should constantly upgrade their knowledge and skills by attending seminars related to accounting, CPD and following the official gazette and other additional literature.

13. Due to the exceptional importance of the accounting service and the constant pressure of deadlines and penalties, the accounting fee / salary should be determined with a tariff according to the following criteria (you can choose more answers):

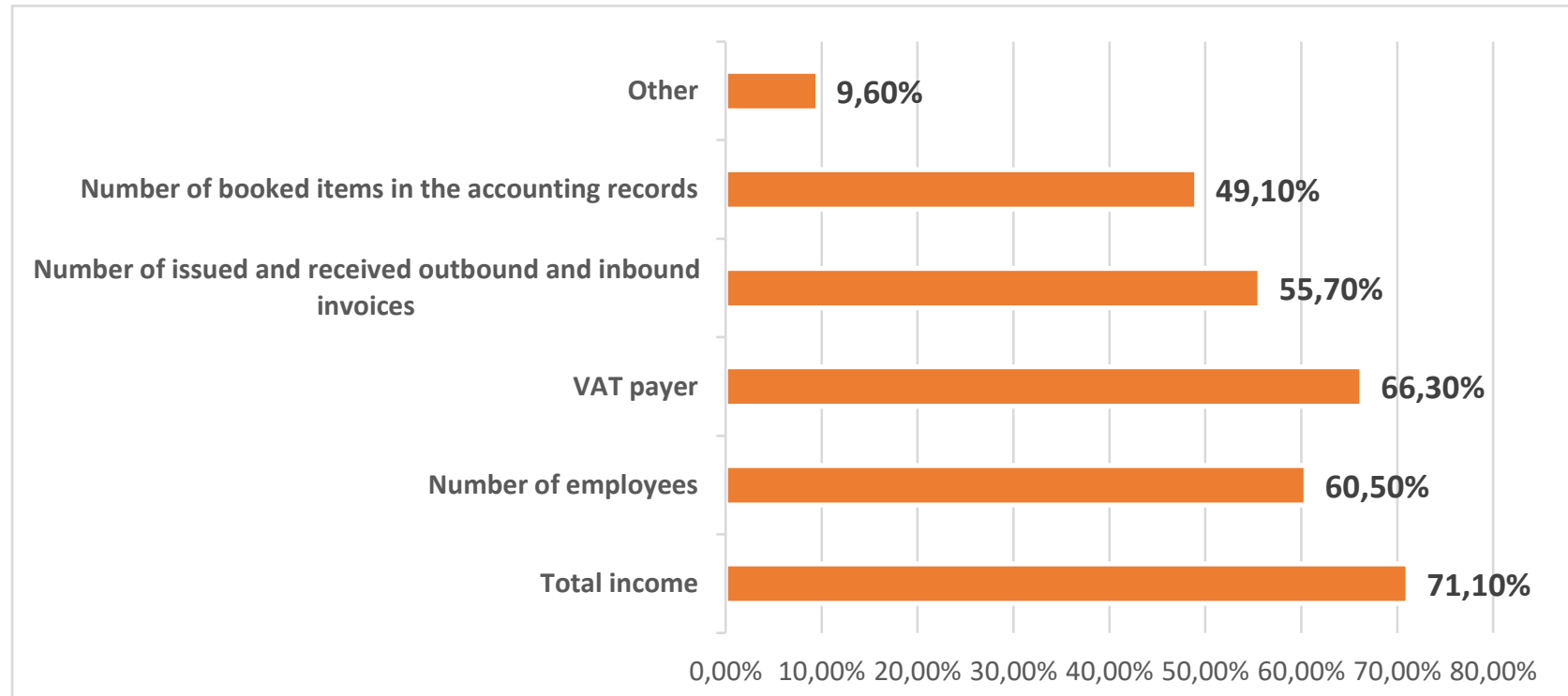

Compensation / salary for accounting should be determined with a tariff in which the total income will be taken into account, the number of employees, whether the client is a VAT payer, number 
of issued and received invoices, number of booked items of the accounting taxpayer, etc. Of course, the liability depending on the size of the accounting payer should be taken into account.

14. The preparation of a new Law on Accounting should be made with a working group in which the following will participate (you can choose multiple answers):

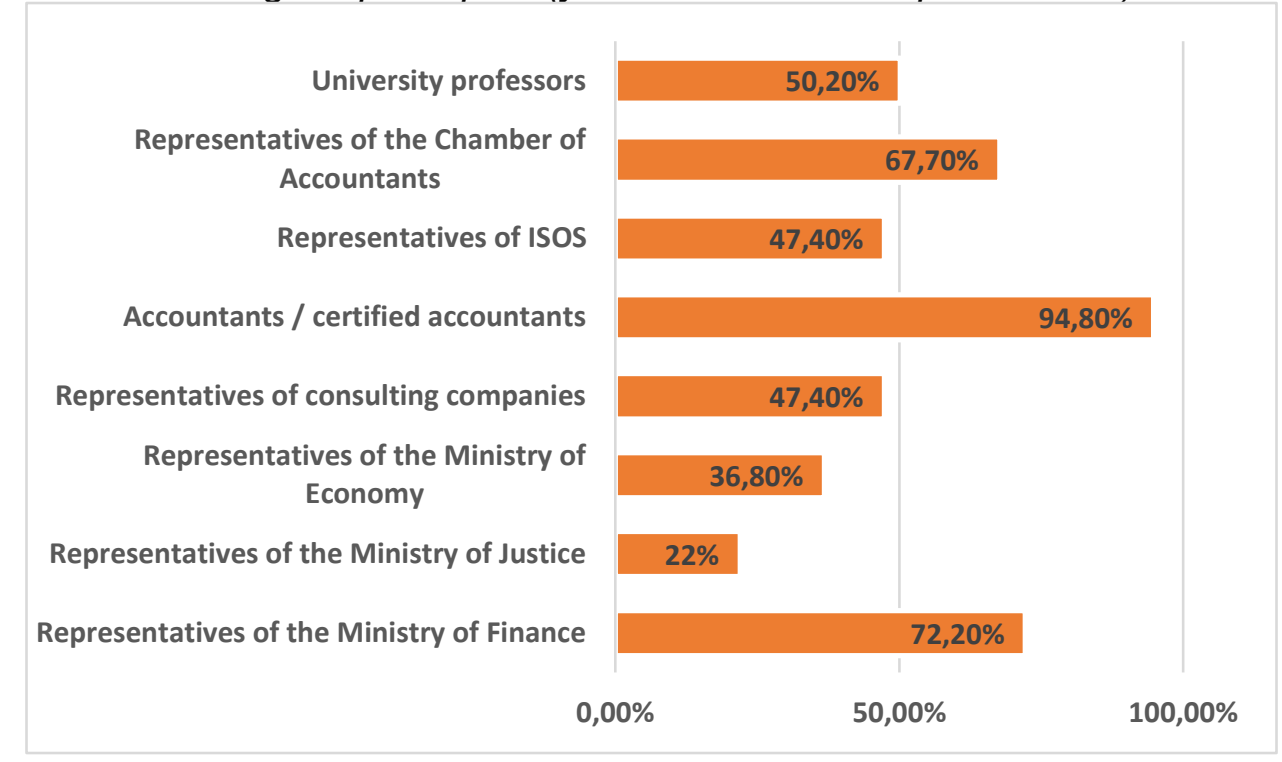

Given the fact that the bodies of ISOS do not function, the need to adopt a new law Law on Accounting is inevitable. More than $50 \%$ of accountants think that the new Law should be prepared by a working group that will include representatives of the Ministry of Finance, accountants / certified accountants, representatives of the Chamber of Accountants and university professors.

15. Due to the frequent change of the existing legal solutions and when adopting new legal solutions, it is obligatory to consult the Accountants / certified accountants as experts from practice?

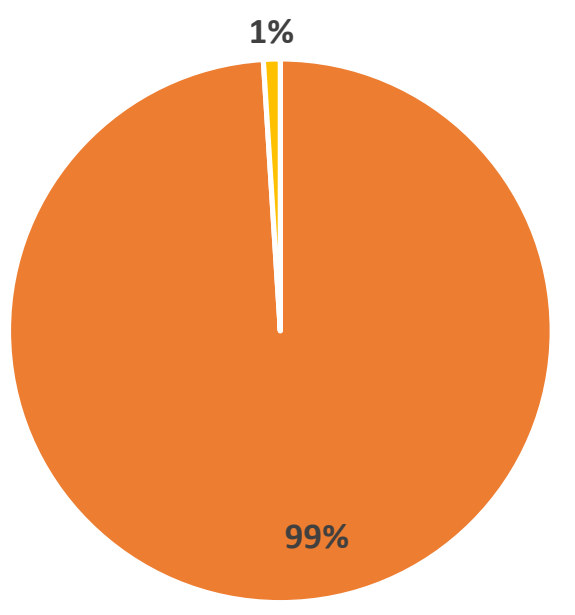

Yes

$\because$ No 
In practice, it often happens that a legal solution, after it is adopted, undergoes numerous changes and additions, which causes ambiguities and obstacles in its implementation. That is why $99 \%$ of the accountants think that when making new legal solutions (whether it refers to the real or the public sector) it is obligatory to consult the Accountants / certified accountants as experts from practice.

\section{Conclusion}

The certified accountant is responsible for the reliability and accuracy of the information presented in the financial statements of the company. The legislation prohibits the accountant from signing an inaccurate or incomplete financial report, i.e., a financial statement that causes misconception and which is contrary to international financial reporting standards. It is necessary to ensure adequate quality in the preparation of financial statements.

The most pressing questions for accountants are how to obtain a certificate for accountant / certified accountant, the number of employees in accounting companies, who should sign and submit annual accounts, financial reports, tax returns and other non-tax forms.

The current law on accounting does not balance the rights with the obligations of the accountants, i.e., they have only obligations with almost no rights. To obtain a license, candidates must have completed secondary education (for accountant) or higher education (for certified accountant) in the field of economics, with work experience of at least 3 years under the supervision of a certified accountant. For comparison - a person with a minimum of secondary education can take the exams for certified accountant of ACCA and after passing the exams and has work experience of at least 3 years under the supervision of a certified accountant becomes a member of ACCA.

The annual accounts, financial reports and forms submitted to the Public Revenue Office should be signed exclusively by a certified accountant. Accountants and certified accountants need to continually upgrade their knowledge by attending seminars for additional knowledge and skills related to accounting. ACCA recognizes a wider range of opportunities to raise the level of knowledge of accountants and requires confirmation of $51 \%+1$ hour of training attended.

The training for CPD of accountants should be organized by ISOS, performed by experts from practice, with theoretical presentations and solving practical problems. Continuing professional training should be provided in combination, with physical presence or online (depending on the participant's choice). The training fee should be included in the annual membership fee. Once licensed as a Chartered Accountant, it is not necessary to renew, given that accountants are continuously upgraded by attending the CPD and other trainings.

Criteria for determining the fee for accounting services should be: total income of the client, number of employees, whether the client is a VAT payer, number of issued and received outbounding and inbounding invoices, number of booked items in the accounting records, etc.

Given the fact that ISOS is non-functional, the need to adopt a new Law on Accounting is inevitable to be prepared by a working group that will include representatives from the Ministry of Finance, consulting companies, accountants / certified accountants, ISOS, the chamber of accountants and university professors. 
Due to the frequent change of the existing legal solutions and when adopting new legal solutions, the accountants / certified accountants as expert must be consulted.

Accountants are extremely important for the business sector and the state, so the accounting profession should be raised to a much higher level, and to act to increase interest in the accounting profession, which is aging.

\section{References}

1. Janka Dimitrova - Will the profession certified accountants in Macedonia become reality?, 2012, https://eprints.ugd.edu.mk/4865/

2. Law on Accounting ("Official Gazette of the Republic of Macedonia" No. 95/12, 188/13, 27/14, 154/15, 192/15, 23/16 and 190/16) - definitions

3. https://isos.com.mk/index.php/za-nas-makedonski/za-institutot

4. https://chamber.mk/komorata-na-smetkovoditeli-se-pridruzhuva-na-protestot-na-tuk/

5. Law on Accounting ("Official Gazette of the Republic of Macedonia" No. 95/12, 188/13, 27/14, 154/15, 192/15, 23/16 and 190/16) - definitions

6. https://www.accaglobal.com/gb/en.html 